\title{
Identification of the Genus Phyllanthus (Family Phyllanthaceae) in Southern Nigeria Using Comparative Systematic Morphological and Anatomical Studies of the Vegetative Organs
}

\author{
Daniel Azubuike Awomukwu ${ }^{1,}$, , Bio Louis Nyananyo², Chiedozie Joel Uka ${ }^{3}$, \\ Clement Uwabunkeonye Okeke ${ }^{3}$ \\ ${ }^{1}$ Department of Biological Sciences, Federal University, Otuoke, Bayelsa State, Nigeria \\ ${ }^{2}$ Department of Plant Science and Biotechnology, University of Port Harcourt, Port Harcourt, Rivers State, Nigeria \\ ${ }^{3}$ Department of Botany, Nnamdi Azikiwe University, Awka, Anambra State, Nigeria
}

\section{Email address:}

xdanny18@yahoo.com (D. A. Awomukwu), bionyananyo@yahoo.com (B. L. Nyananyo), dozemancentury@yahoo.com (C. J. Uka), clementuokeke@yahoo.com (C. U. Okeke)

\section{To cite this article:}

Daniel Azubuike Awomukwu, Bio Louis Nyananyo, Chiedozie Joel Uka, Clement Uwabunkeonye Okeke. Identification of the Genus Phyllanthus (Family Phyllanthaceae) in Southern Nigeria Using Comparative Systematic Morphological and Anatomical Studies of the Vegetative Organs. Journal of Plant Sciences. Vol. 3, No. 3, 2015, pp. 137-149. doi: 10.11648/j.jps.20150303.15

\begin{abstract}
Five species of Phyllanthus L. Family Phyllanthaceae occurring in Southern Nigeria, P. amarus Schum and Thonn, P. urinaria Linn., P. odontadenius Mull-Arg., P. niruroides Mull-Arg. and P. muellerianus (O. Ktze) Excell were compared using the morphology and anatomy with the view to adding to increasing the systematic lines of evidence and providing a more natural clarification than the existing one. The foliar and floral morphology of these species were described while the anatomical characteristics of the leaf, stem and root are valuable characters in delimiting the species. The results obtained from the studies showed that species of Phyllanthus have different attributes in their vascular characteristics that could be used together with other existing systematic evidence in clarifying the confusion in identifying these plants. Evidence from the nature of the palisade parenchyma in the mesophyll, nature of the collenchyma, sclerenchyma and vascular bundles are presented and discussed with their values in the systematic positions of these plants. A dichotomous bracketed key to the identification of the species studied is provided.
\end{abstract}

Keywords: Phyllanthus Species, Morphology, Anatomy, Taxonomic Evidence

\section{Introduction}

The genus Phyllanthus L. is a member of pantropical family Phyllanthaceae (a segregate from Euphorbiaceae sensu lato [s.1.]) based on congruent plastid and nuclear DNA sequence data that have recovered well-resolved and strongly supported clades (Wurdack et al., 2004; Samuel et al., 2005; Kathriarachchi et al., 2005) that correspond to subfamilies and tribes. Estimates in the number of species in this genus vary widely from 750 (David, 2008) to 1200 (Kathariarachchi et al., 2005). Some of these species occur in the southern Nigeria and all tropical regions of the world from North Central and South America (Uander and Blumberg, 1991). The plants are monoecious; leaves simple, alternate or opposite, some are leathery, flowers are very small and diclinous, they cluster in cup-shaped structures, greenish, whitish or whitish-green, often with glands. The fruit is a lobed-capsule extending from the cup and commonly the long stalk pendant (Lewis and Elvin-Lewis, 1977; Wessels-Boer et al., 1976). The name "Phyllanthus" means "leaf and flower" because the flower, as well as the fruit, seems to become one with the leaf. Other common names include gripe weed, stonebreaker, leaf flower etc (Cabieses, 1993). The medicinal values of these plants lie in some chemical substances that produce a definite physiological action on the human body. Nigeria is one country is rich in raw and useful herbs from which important drugs could be prepared or agent which serve as starting 
products for the potential synthesis of drugs (Sofowara, 1993). Members of the Phyllanthus designated as weeds are used as pot herbs. The healing powers of Phyllanthus as claimed by local medicinal practitioners range from headache, skin diseases to gonorrhea and syphilis (Akobundu and Agyaka, 1987, Burkill, 1994). Other aliments treated with these medicinal plants include asthma, cough, diarrhea, diabetes, malaria, eye and ear problems, indigestion and constipation, nausea and vomiting, bleeding, childcare, healing of wounds and sores and tooth extraction. Some of these medicinal plants are used as styptic and as simple laxative to cure dysentery. They are a good source of pesticides (Oliver, 1959; Burkill, 1994 and Gill, 1992). Most of these plants used for traditional medicine are equally consumed by humans in the Niger-Delta region of Nigeria, but their correct identification poses problems to the users.

Morphological characters are features of external forms or appearance. They currently provide the characters used for hypothesizing phylogenetic relationships. These features have been used for a longer time than the anatomical evidence in the beginnings of plant systematic. Morphological characters are easily observed and find practical use in keys and description. Morphological characters include the external features of the plant parts used, including the particulars of their size, shape and colour. Most plants are classified based on external morphological structures, such as flower and fruits. These structures are not always available on plants because they are seasonal in production.

Anatomical studies are a systematic line of evidence used in combination with other systematic lines to arrive at a good taxonomic condition (Stace, 1980). Anatomical studies apart from special references to systematic position of the taxa can also be used in noting the origin, natural distribution extent of cultivation and cultivars within species of plants (Lawson, 1967; Onwueme, 1978). The significant role of vegetative anatomy in botanical reconstruction of the origin, natural distribution, extent of cultivation and cultivars within species of plants dates back to many centuries ago. Metcalfe and Chalk (1950) dealt extensively on the relative importance of anatomical features in the systematic positioning of groups of angiosperms. In spite of this, different authors in different groups have studied the scientific importance and specific implication of anatomical features of Phyllanthus amarus only. They include Natural Remedies-Research Centre (2006); Edeogaet al., (2007). None of such works has successfully delineated the indigenous species occurring in the southern Nigeria which includes $P$. amarus Schum and Thonn, $P$. urinaria Linn. and $P$. odontadenius Mull-Arg., $P$. niruroides Mull-Arg. and P. muellerianus (O. Ktze) Excel

From available literature, series of documented descriptions of the morphological characteristics and ethnobotanical uses of Phyllanthus are found have been reported (Burkill, 1994; Oliver, 1959; Hutchinson and Dalziel, 1963), there is confusion in recognizing individual species of these plants in Nigeria. Therefore the basic anatomical information provides data that will clarify the confusion in the identity of these taxa. The aim of this work was to provide comprehensive information on the morphological and anatomical structures that will clarify the confusion in the identification of these Phyllanthus species. The information provided therein will go a long way in aiding workers who may use these plants for other purposes, such as pharmaceutical, biological and other related areas of study.

\section{Materials and Methods}

\subsection{Collection of Plant Materials}

Mature plants of the five species $P$. amarus, $P$. urinaria, $P$. niruroides, $P$. odontadenius and $P$. muellerianus. were collected from different locations of southern Nigeria (bounding box coordinates: upper left $-6.3333,7$; lower right $-4.75,6.8333$ ) by various investigators as in Table 1. Only healthy, fresh and succulent parts of the plants were collected. The five specimens were identified and authenticated at the Herbaria of the Department of Plant Science and Biotechnology, Michael Okpara University of Agriculture, Umudike, Umuahia, Abia State and the Department of Botany, NnamdiAzikiwe University, Awka, Anambra State. Herbarium specimens were also studied at the various institutions as well making reference to the Flora of West Tropical Africa by Hutchinson and Dalziel (1963). The accessions were deposited at the Herbarium of the Department of Plant Science and Biotechnology, University of Port Harcourt, Port Harcourt, Rivers State, Nigeria with their sample and process identity numbers for further research.

Table 1. Collection sites, identity numbers and collection dates of the five Phyllanthus species studied.

\begin{tabular}{|c|c|c|c|c|c|}
\hline Species & Site of collection & Coordinate elevation & Sample ID & Process ID & Date of collection \\
\hline P. amarus & $\begin{array}{l}\text { Along the school fence, Abia State } \\
\text { Polytechnic, Aba. }\end{array}$ & N5.42; E6.33;25.0m & AWOM UPH PA 010 & PHSN 001-14 & April 15, 2014 \\
\hline P. urinaria & $\begin{array}{l}\text { Field around National Root Crop Research } \\
\text { Institute, Umudike. }\end{array}$ & N4.75; E6.83; 20.0m & AWOM UPH PN 050 & PHSN 003-14 & April 14, 2014 \\
\hline P. odontadenius & $\begin{array}{l}\text { Road side along National Root Crop } \\
\text { Research Institute, Umuahia. }\end{array}$ & N5.42; E7.50; 25.0m & AWOM UPH PO 040 & PHSN 006-14 & April 15, 2014 \\
\hline P. niruroides & $\begin{array}{l}\text { Science Village, Nnamdi Azikiwe } \\
\text { University, Awka. }\end{array}$ & N6.33; E7.00; 22.0m & AWOM UPH PU 030 & PHSN 005-14 & April 15, 2014 \\
\hline P. muellerianus & $\begin{array}{l}\text { Near the Herbarium Building, Nnamdi } \\
\text { Azikiwe University, Awka. }\end{array}$ & N6.33; E7.00; 23.0m & AWOM UPH PM 020 & PHSN 002-14 & April 15, 2014 \\
\hline
\end{tabular}




\subsection{Morphological Studies}

This involves the observation of the qualitative foliar floral characteristics of the species as well as measurement of the quantitative morphological characters of the leaves and flowers of the five species studied.

\subsection{Anatomical Studies}

Section 22-26mm thick prepared from the leaves, stems and roots were fixed in Formalin Aldehyde Acetone (1:1:18) for 48-72hours. These were then rinsed in several alcohol series $(30,50,70,95$ and $100 \%)$. These dehydrated materials were infiltrated with wax by passing trough different proportions of alcohol and chloroform $(3: 1,1: 1$, 1:3 pure chloroform $\mathrm{v} / \mathrm{v}$ ). As the chloroform gradually replaced the alcohol, wax was put in the bottles to slowly infiltrate the tissue with wax to make it hard enough for sectioning.

The bottles were left on a hot plate $\left(37-40^{\circ} \mathrm{C}\right)$ for 24 hours before transferring to the oven $\left(58-60^{\circ} \mathrm{C}\right)$ (this procedure evaporates the chloroform). The wax at its melting point completely infiltrated the tissues in it. After a period of 2-3 days with constant addition of wax the specimens were embedded in paraffin melted wax. This was accomplished by a quick orientation of the specimens in the mould with a hot mounted needle and forceps and quick cooling in a beaker containing ice block. The resultant wax blocks were later trimmed and sectioned on a Reichert rotary microtome at $20-24 \mathrm{~mm}$ following a slightly modified method (Culter, 1978).

The ribbons were placed on clean slides smeared with a film of Hampt's albumen and allowed to dry and drops of water added prior to mounting. The slides were placed on a hot plate at $40^{\circ} \mathrm{C}$ for a few minutes to allow the ribbons to expand and were stored over night. The slides were immersed in pure xylene for 2-5 minutes in a solution of xylene and absolute alcohol with 1:1 ratio $(\mathrm{v} / \mathrm{v})$ for 5 minutes. The slides were then transferred to another solution of xylene and alcohol in the ratio of $1: 3(\mathrm{v} / \mathrm{v})$ for a few minutes, to $95,90,70$ and $50 \%$ alcohol. Drops of alcian blue were added to the specimens for 5 minutes, washed off with water and counter-stained with safranin for 2 minutes, then dehydrated in a series of alcohol 50,70, 80, 90\% and pure xylene at intervals of a few seconds and mounted in Canada balsam. Coloured photomicrographs were taken using a LeitzWetzlerOrtholux microscope fitted with a Vivatar-V-335camera.

\section{Results and Observation}

\subsection{Morphological Description}

A summary of the morphological differences and similarities observed in the five species of Phyllanthus is presented in Table 2 while the detailed morphological description of each of the species is presented below.

Table 2. Summary of important features of the Phyllanthus species studied.

\begin{tabular}{|c|c|c|c|c|c|}
\hline \multirow{2}{*}{ Characters } & \multicolumn{5}{|l|}{ Taxa } \\
\hline & P. amarus & P. urinaria & P. odontadenius & P. niruroides & P. muellerianus \\
\hline \multirow[t]{2}{*}{ Habit } & Herb & Herb & Herb & Herb & Shrub \\
\hline & $5-10 \mathrm{~mm}$ long & $6-15 \mathrm{~m}$ long & $6-15 \mathrm{~mm}$ long & 4-10mm long & $2-7 \mathrm{~cm}$ long \\
\hline \multirow[t]{2}{*}{ Leaf size and shape } & $2-4 \mathrm{~mm}$ broad & $3-15 \mathrm{~mm}$ broad & $5-7 \mathrm{~mm}$ broad & $1.5-3 \mathrm{~mm}$ broad & $1.5-4 \mathrm{~cm}$ broad \\
\hline & Elliptic-oblong & Oblong & Oblong & Oblong & Ovate-elliptic \\
\hline Leaf apex & Obtuse & Mucronate & Obtuse & Mucronate & Subacute \\
\hline Stem colour and form & $\begin{array}{l}\text { Greenish, smooth, } \\
\text { rounded, glabrous } \\
\text { and woody at } \\
\text { base. }\end{array}$ & $\begin{array}{l}\text { Reddish-green, smooth, } \\
\text { pentagonal, glabrous and } \\
\text { woody at base. }\end{array}$ & $\begin{array}{l}\text { Greenish, smooth, } \\
\text { pentagonal, glabrous and } \\
\text { woody at base. }\end{array}$ & $\begin{array}{l}\text { Greenish, smooth, } \\
\text { pentagonal, } \\
\text { glabrous and } \\
\text { woody at base }\end{array}$ & $\begin{array}{l}\text { Brownish-green, } \\
\text { thorny, rounded- } \\
\text { pentagonal, glabrous } \\
\text { and all-woody }\end{array}$ \\
\hline Fruit and flower colour & $\begin{array}{l}\text { Greenish fruits } \\
\text { and tepals }\end{array}$ & $\begin{array}{l}\text { Reddish fruits and reddish- } \\
\text { green tepals }\end{array}$ & $\begin{array}{l}\text { Greenish fruits and } \\
\text { whitish-green tepals }\end{array}$ & $\begin{array}{l}\text { Spotted- greenish } \\
\text { fruits andtepals }\end{array}$ & $\begin{array}{l}\text { Berry-like red fruits } \\
\text { and greenish tepals }\end{array}$ \\
\hline Number of tepals & Pentatepalous (5) & Hexatepalous (6) & Hexatepalous(6) & Pentatepalous (5) & Pentatepalous(5) \\
\hline Nature of stipules & $\begin{array}{l}\text { Greenish and } \\
\text { laterally free }\end{array}$ & Reddish and laterally free & $\begin{array}{l}\text { Reddish and laterally } \\
\text { free }\end{array}$ & $\begin{array}{l}\text { Reddish and } \\
\text { laterally free }\end{array}$ & Greenish and spiny \\
\hline Plant height & Up to $75 \mathrm{~cm}$ high & Up to $60 \mathrm{~cm}$ high & Up to $1.0 \mathrm{~m}$ high & Up to $75 \mathrm{~cm}$ high & Up to $12 \mathrm{~m}$ high \\
\hline
\end{tabular}



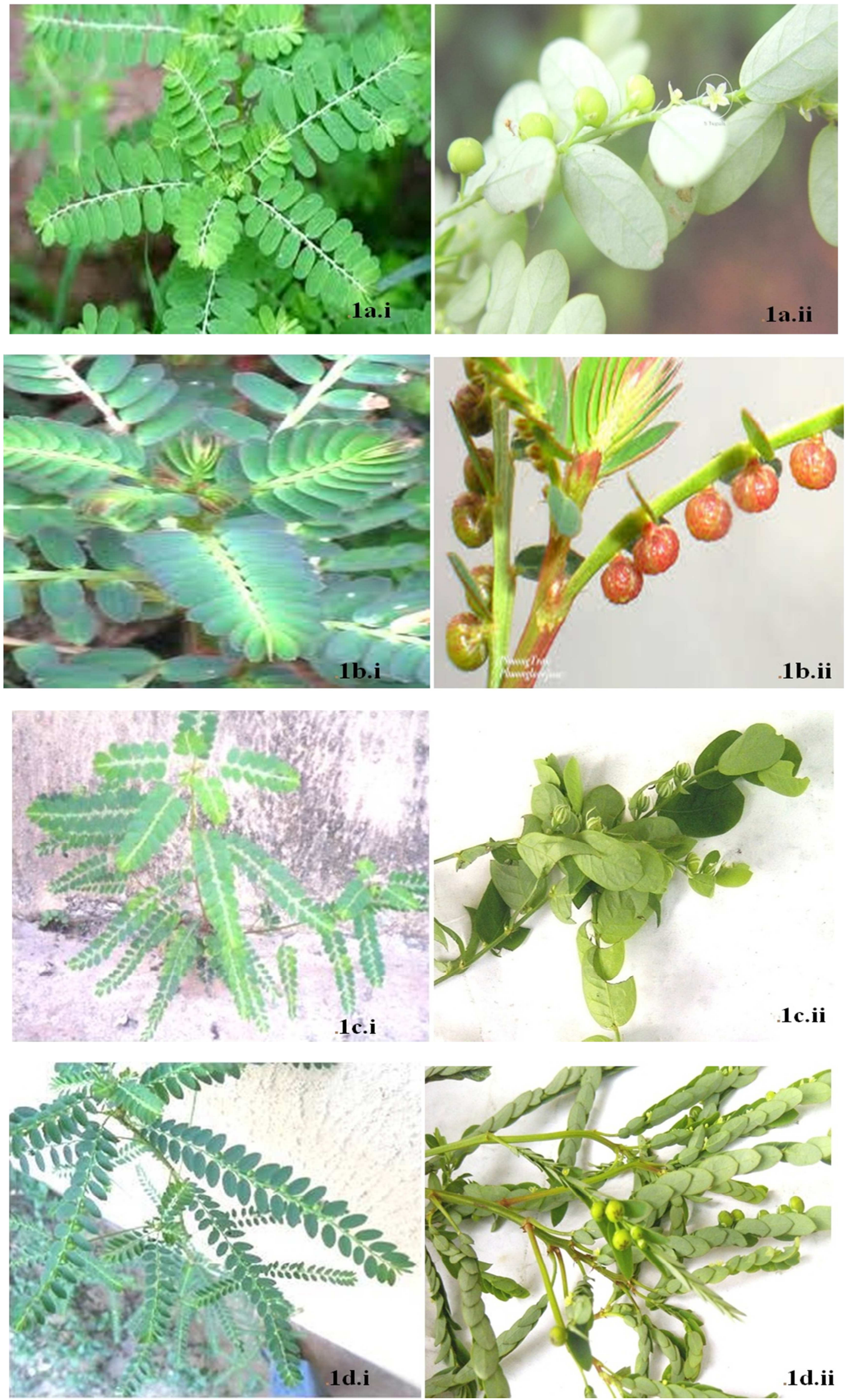


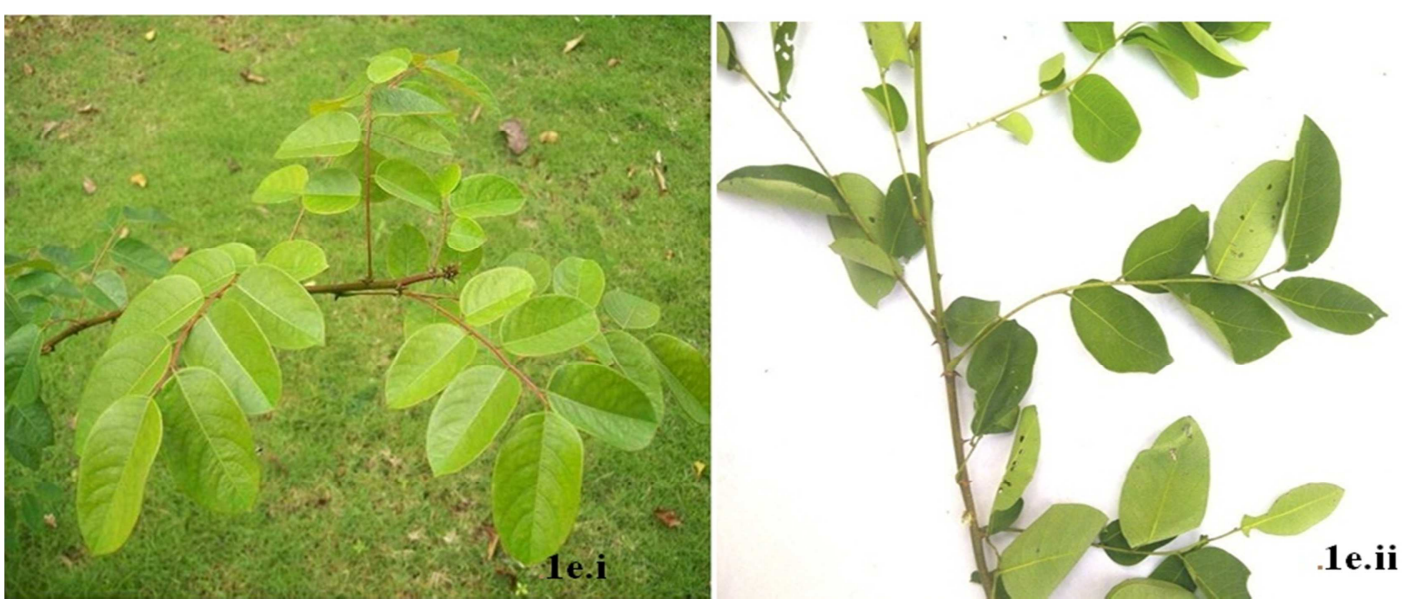

Figure 1. Photographs of the morphology of the genus Phyllanthus studied.

(a.i) P. amarus, showing the dorsal surface of the herb and the elliptic-oblong shape of the leaves.

(a.ii) P. amarus, exposing the greenish fruits and the pentatepalous flowers on the ventral surface of the leaves.

(b.i) P. urinaria, showing the dorsal surface of the herb andthe mucronate leaf apices .

(b.ii) P. urinaria, exposing the reddish-green friuts, stipules and buds on the ventral surface of the leaves.

(c.i) P. odontadenius, showing the dorsal surface of the herb and the oblong shape of the leaves.

(c.ii) P. odontadenius, exposing the whitish-green tepals and reddish laterally free stipules.

(d.i) P. niruroides, showing the dorsal surface of the herb and the mucronate leaf apices.

(d.ii) P. niruroides, exposing the greenish fruits and tepals and reddish laterally free stipules.

(e.i) P. muellerianus, showing the dorsal surface of the shrub branch and the ovate-elliptic shape of the leaves.

(e.ii) P. muellerianus, exposing the spiny stipules of the leaves and thorny branches.

\subsubsection{Phyllanthus amarus Schum and Thonn}

F.T.A. 6, 1: 717; Chev.Bot 556. S.L.: Bonthe (fl\&fr. Nov) Deighton 2265! Kent (fl.\&fr. May) Deighton 2657! Rokupr (fl\&fr. Apr) Jordan 237! Njala (fi.\&fr. May) Deighton 1945! Lik, : Monrovia Whyte! Since Basin Whyte! Iv.C.: fide Chev. I.c. G.C.: Thonning. Axin (Jan) Chipp 56.1 Accra Ansell! N.Nig.:Idah T. Vogel! S. Nig.: Lagos Dewodu 24! 365! Dulx.1380 !Sapohn Kennedy 2896 !Awka Thomas 50 !Calabar (fi.\&fr. Mar.) Brenan 9210 ! F. PaT. Vogel!.

A glabrous, erect or ascending annual herb up to $75 \mathrm{~cm}$ tall. It is much branched with small leaves on lateral branches of the stem that give the plant the appearance of having pinnate leaves reproducing from seeds. The stem is rounded, woody at the base, horizontally branched, smooth and greenish, monoecious or rarely dioecious. The leaves are alternate, elliptic on long, $5-10 \mathrm{~cm}$ long and $2-4.5 \mathrm{~mm}$ broad, pale beneath and with short petioles. The inflorescence is axiliary in and consists of one male flower and one female flower in each axil. Flowers are greenish and rather small up $1.5 \mathrm{~mm}$ diameter. Female flowers usually solitary in the proximal axils. The fruit is a round capsule, brownish, $1.5-2 \mathrm{~mm}$ across and occurs in least axils on the lower side of the lateral branches. Each capsule contains six small seeds (Akobundu and Agyaka, 1987; Hutchinson and Dalziel, 1963).

\subsubsection{Phyllanthus urinaria Linn}

F.T.A. 6, 1 : 721. S. L.: Regent, on rocks (Dec.) Sc. Elliot 4102 ! Freetown (Dec.) Deighton499 !Moyamba (fl. \&fr. Aug.)Deighton2215 !Sembehun (fl. \&fr. Aug.)Deighton3794 !Rokupr (fl. \&fr. Apr.) Jordan 238 ! G.C.: Benso, Tarkwa (fl. \&fr. June) Andoh FH 5525 ! S. Nig. :Sapoba (fr. Sept.) Onochie FHI 34311 !
This is a small, slender, sub-woody, annual herb up to $60 \mathrm{~cm}$ high $/ 9-12$ inches or 2 feet high. It has numerous small leaves on lateral branches of the stem resembling mimosa tree, disposed in two ranges. The leaves are large at the tip and towards the petiole. When touched, the leaves fold in automatically. The leaves are alternate, oblong, rounded at base, shortly pointed and minutely mucronate at apex, 6$15 \mathrm{~mm}$ long and $3-5 \mathrm{~mm}$ broad, margins asperulate. The stem is glabrous, round, sub-woody at the base, horizontally branched, pentagonal and greenish at the top. Petiole very short and compressed, glabrous, stipules broad and articulate at the base, narrowed into a filiform point, about $3 / 4$ lin long. Flowers are solitary and subsessile, monoecious with warted ovary. The flowers are greenish-red with sepals 6 , minute and appear at axiles of the leaves as well as the seed capsules. Numerous small green-red fruits, round and smooth are found along the underside of the leaves which are erect and red. The fruit is round capsule, greenish and when ripe with reddish-green sepal along a green margin. The seeds are transversely ridged with about 10 prominent transverse ribs on the back (Burkill, 1994; Hutchinson and Dalziel, 1963).

\subsubsection{Phyllanthus odontadenius Mull-Arg}

F.T.A. 6, 1 : 727. Port. G.: Bissau (Nov.) Esp. Santo 897 ! S.L.: Njala (fl. \&fr. May) Deighton639 !Rokupr (fl. \&fr. Apr.) Jordan 236 !Bafodea (fl. \&fr. May) Deighton4480 ! Lib.: KakatownWhyte ! G.C.: Aburi Hills (fl. \&fr. Oct.) Johnson 471 ! Kumasi Cummins 77! S.Nig.: Lagos (fl. \&fr. July) Dalz. 1361 !Ibadan (fl. \&fr. Nov.Apr.)Meikle652 !1306 !1454 !Okomu F. R. (fl. \&fr. Feb.) Brenan 9135 !9148 !Calabar (fl. \&fr. Mar.) Brenan 9209 !Br.Cam.:Buea (fl. \&fr. July) Dundas FHI 15237! F.Po: 
Barter !Extends to A.-E.Sudan and Angola, also on S. Tome.

This is a glabrous, erect or ascending, sub-woody annual herb up to $1 \mathrm{~m}$ tall. It is much branched with leaves on lateral branches of the stem giving the plant appearance of having pinnate leaves up to $90 \mathrm{~cm}$ high reproducing from seed. The stem is brownish glabrous, round, sub woody at the base, horizontally branched, pentagonal and greenish at the top. The leaves are large at the tip and towards the petiole. The leaves are alternate, oblong, rounded at the base, obtuse at apex, 6-15mm long and $5-7 \mathrm{~mm}$ broaded. The branchlets are flattened and winged with distinct red stipules up to $2 \mathrm{~mm}$ long, not conspicuous. The flowers are monoecious with the inflorescence consisting of male flowers 2-3 together in lower leaf axils of branches, females solitary in upper axils and larger. Tepals are 6, oblong-linear, not completely enclosing the fruit. The ovary is very shortly stipitate. The fruit is a round capsule, greenish, and $1.7-2 \mathrm{~mm}$ across. The flowers are whitish-green, small on short pedicels (Burkill, 1994; Hutchinson and Dalziel, 1963).

\subsubsection{Phyllanthus muellerianus (O. Ktze.) Excell}

F.T.A. 6, 1 : 701; F.W.T.A., ed. 1, 1 : 290 ; Chev. Bot. 556 ;Aubrev. Fl. For. Soud.-Guin. 189.Fr.Sud.: Bamako Waterlot 1368. BirgoDubios 210. Port.G.: Granja, Catio (June) Esp. Santo 2088 ! Fr. G.:Rio Nunez Heudelot659 !Kouroussa (June) Pobeguin264 !812 !S.L. Wilberforce (fr. Mar.) Johnston 96 !Mofari, Scarcies R. (Jan.) Sc. Elliot 4402 !Njala (fl. Mar., fr. Apr.)Deighton1097 !1824 !4742 !Batkanu (Jan.) Deighton2863 ! Lib.: Tappita (fr. Aug.) Baldwin 9100 !Flumpa, Sanokwele (fr. Sept.) Baldwin 9354 !Kulo, Sinoe (fr. Mar.) Baldwin 11437 !Soplima, Vonjama (Nov.) Baldwin 10111a! Iv.C.:Baoule, Ferkessedougou, BoboDioulasso and Kampti fide Aubrev. 1.c. G.C.: Axim (Mar.) Chinn 395 !Kumasi (fl\&fr. Feb.) Irvine 119 !Assuantsi (Jan., Mar.)Fishlock6 ! Irvine 1561 !Dah.:DjougouChev. 23875. N. Nig.: Nupe Barter 1656 !Zungeru (July) Dalz.64 ! S. Nig.: Lagos Rowland! Ibadan (Feb.) Meikle1149 !Okomu F. R. (Feb.) Brenan 9039 ! Old Calabar (Feb.) Mann 2262 !Br.Cam.:Buea (Mar.) Maitland 499 ! F.Po: Mann 12 !

A glabrous shrub or woody climber up to $12 \mathrm{~m}$ tall, sometimes arborescent, often armed recurvedstipular spines, with copious inflorescences of minute greenish flowers, and small berry-like red fruit.Monoecious, branches spreading or pendulous, main branches stout, angular, reddish tinged, branchlets $15-20(-25) \mathrm{cm}$ long, with several short axillary shoots; branch basis transformed into a pair of spines c. 4 $\mathrm{mm}$ long, purplish brown. Leaves alternate, distichous along lateral twigs, simple, glabrous; stipules lanceolate, c. $2 \mathrm{~mm}$ long, acuminate; petiole $3-5 \mathrm{~mm}$ long; blade ovate, ellipticalovate to ovate-lanceolate, $3-9 \mathrm{~cm} \times 2-4.5 \mathrm{~cm}$, base cuneate to rounded, apex acute to obtuse, with 10-14 pairs of lateral veins. Inflorescence a false raceme on short axillary shoots, 2-6 cm long, solitary or several together, with flowers in clusters having 2-3 male flowers and 1 female flower in each cluster. Flowers unisexual; perianth lobes 5, elliptical, c. 1 $\mathrm{mm}$ long, rounded, greenish white or greenish yellow; male flowers with pedicel c. $1.5 \mathrm{~mm}$ long, disk glands 5, free, minutely warted, fleshy, stamens 5 , free, unequal, anthers very small; female flowers with stout pedicel c. $1 \mathrm{~mm}$ long, disk glands 5, free or fused, knobbly, fleshy, ovary superior, ellipsoid, warty, 4-5-celled, styles 4-5, free, c. $0.5 \mathrm{~mm}$ long, 2-fid at apex. Fruit a fleshy, nearly globose capsule 3-4 mm in diameter, usually smooth, green, becoming red, later black, 6-seeded. Seeds angular, c. $1 \mathrm{~mm}$ long, with faint ridges, bright reddish brown or yellowish brown (Burkill, 1994; Hutchinson and Dalziel, 1963).

\subsubsection{Phyllanthus niruroides Mull-Arg}

F.T.A. 6, 1 : 715 ; Chev. Bot. 558.Fr.G.:KouriaChev. 14839. S.L.: Freetown Welw. 316 !Kambia (fl. \&fr. Dec.) Sc. Elliot 4346 !Newton (fl. \&fr. Sept.)Deighton4878 !Rokupr (fl. \&fr. Apr., Aug.)Deighton3019 ! Jordan 235 ! Bo (fl. \&fr. June) Deighton5102 ! Lib.: Gbanga (fl. \&fr. Sept.) Linder 522 !Monrovia (fl. \&fr. June, Nov.) Baldwin 5871 ! Barker 1462 !Mt. Barclay (fl. \&fr. Apr.)Bunting ! Togo: Misahohe Baumann 144 (partly). S.Nig.:Calabar (fl. \&fr. July) Holland 44 !Also in French Cameroons, Gabon, Belgian Congo, Tanganyika and S. Rhodesia.

This is an annual herb much branched, semi-woody, erect up to $75 \mathrm{~cm}$ high. The stem is brownish, glabrous and woody at the base. The leaves are oblong with mucronate apices, 4$10 \mathrm{~mm}$ long, $1.5-3 \mathrm{~mm}$ broad, pale beneath and with short petioles. The inflorescence consisting of male flowers 2-3 together in lower leaf axils of branches, female solitary in upper axils; disk of female flower stellate with 5 deep lobes; style very short, deeply bifid. Tepals of both sexes 5 , those of the females in a single series. Ovary prominently warted; curved back of seed marked with 12-14 fine longitudinal ridges. The fruit is a round capsule, greenish and $1.7-2 \mathrm{~mm}$ across and occurs in leaf axils on the lateral branches. The flowers are light-green, small on short pedicels (Burkill, 1994; Hutchinson and Dalziel, 1963).

\subsection{Dichotomous Bracketed Key to the Morphology Identification of the species of Phyllanthus studied}

1. Habit, shrub; stipules, spiny .................. P. muellerianus.

$1^{\mathrm{I}}$. Habit, not shrub but herb; stipules, laterally free ......... 2

2. Leaves, elliptic-oblong; stipules, greenish; stem form, rounded. P. amarus.

$2^{\mathrm{I}}$. Leaves, not elliptic-oblong but oblong; stipules, reddish; stem form, pentagonal ........................ 3.

3.Tepals, pentapetalous (5); fruits often spotted ............................. P. niruroides.

$3^{\mathrm{I}}$.Tepals, not pentapetalous but hexapetalous (6); fruits not spotted .... 4.

4. Leaf apices, mucronate; stem, fruit and flower, reddishgreen .................... P. urinaria.

4. Leaf apices, not mucronate but obtuse;stem, fruit and flower, not reddish-green but green ............. P. odontadenius. 


\subsection{Anatomical Observation}

The results are presented in Table 3 and Fig 2-4. The epidermis of the five species was one layer thick. The mesophylls are differentiated into palisade and spongy parenchyma layers but these vary from species to species. The palisade parenchyma was 1 layer thick in $P$. odontadenius (Fig. 2c) and P. muellerianus (Fig. 2e), but 2 layers thick in P. amarus (Fig. 2a), P. urinaria (Fig. 2b) and $P$. niruroides (Fig. 2d). Large intercellular spaces occurred in the spongy paranchyma of $P$. urinaria, $P$. odontadenius and $P$. muellerianus while $P$. amarus and $P$. niruroides have small intercellular spaces. The distribution of the collenchyma cells within the midrib of the studied species varied as well. $P$. amarus, $P$. niruroides and $P$. muellerianus possessed collections of collenchyma cells on both the adaxial and abaxial portions of the leaf while, $P$. urinaria and $P$. odontadenius displayed none on the adaxial but posses a few layers (1-2 layers respectively) on the abaxial portion. The vascular bundles consisting of the xylem, phloem and sclerenchyma possessed no bundle sheath. The nature of the xylem cells within the midrib varied within the five species.P. amarus (2 layers thick), P. niruroides (6 layers thick) and $P$. muellerianus (7 layers thick) contained elongated xylem cells, while $P$. urinaria (2 layers thick) and $P$. odontadenius (3 layers thick) contained clustered xylem cells. The result showed that the vascular bundles of the five species have C3 anatomy: the vascular bundles are surrounded by small cells of the mesophylls devoid of chloroplast.

The stems of the five species consist of a single layer of somewhat spherical epidermis. The transverse section of $P$. urinaria, $P$. odontadenius and $P$. niruroides showed the presence of ridges and furrows while $P$. amarus and $P$. muellerianus posses none. The epidermis being a single outermost layer passes over the ridges and furrows. The presence of the ridges and furrows is as result of the angular and pentagonal nature of the epidermal circumference on the stems. The hypodermis (collenchymas) lies externally, the general cortex lies in the middle and endodermis lies internally. The hypodermis ranged from 2-3 layers in $P$. amarus (Fig. 3a), 2-5 layers in P. urinaria (Fig. 3b), 3-4 layers in $P$. niruroides (Fig. 3d), 3-5 layers in $P$. odontadenius (Fig. 3c) and P. muellerianus (Fig. 3e) respectively. Also, the shapes of the collenchymas varied from oval in $P$. niruroides to rectangular in $P$. amarus, $P$. urinaria, $P$. odontadenius and $P$. muellerianus respectively. The furrows in $P$. urinaria and $P$. niruroides consisted of about 1-2 layers collenchymatous cells respectively while $P$. odontadenius consisted of about 2-3 layers. The general cortex or cortical parenchyma forms narrow zone in the middle which ranged from 4-6 layers thick in $P$. amarus, 25 layers thick in P. urinaria and P. niruroides, 2-3 layers thick in $P$. odontadenius and 5-7 layers in $P$. muellerianus. Also, the shapes varied from oval in $P$. amarus and $P$. niruroides, oval and polygonal in $P$. urinaria and $P$. odontadenius to oval and rectangular in $P$. muellerianus. The endodermis lies immediately outside the pericyclic sclerenchyma. The pericycle, which represents the sclerenchyma; which is thick-walled and lignified is 2-3 layers thick in P. amarus and P. muellerianus, 2-5 layers thick in $P$. urinaria, and 1-2 layers thick in $P$. odontadenius and 3-4layers thick in $P$. niruroides. The vascular bundles which include the xylem and phloem were arranged in ring form. The phloem vessels lay over head the xylem vessels. The phloem ranged from 4-9 layers thick in $P$. amarus and $P$. odontadenius, 3-5 layers in $P$. urinaria, 2-7 layers in $P$. niruroides and 3-5 layers in $P$. odontadenius while the number of elongated cells in xylem vessels ranged from 3-6 cells in $P$. amarus, $2-5$ cells in $P$. urinaria and $P$. odontadenius, 2-8 cells in $P$. niruroides and 5-13 cells in $P$. muellerianus.

The roots of all the five species investigated are composed of an outer layer piliferous layer that is one layer thick in all the species studied. This layer is followed by thin walled cork cells. The cork cells varied from species to species. The cork cell was 5-9 cells thick in P. amarus (Fig. 4a), 8-11 cells thick in $P$. urinaria(Fig. 4b), 6-9 cells thick in $P$. odontadenius (Fig. 4c), 2-4 cells thick in $P$. niruroides (Fig. 4d) and 3-5 cells thick in P. muellerianus (Fig. 4e). The cortex of the species were seen as conspicuous as rays of cells rising from the middle which are composed of layer thin-walled, colorless paranchymatous cells with vascular bundles at the centre of the root. The cortex varied from 1015 cells thick in $P$. amarus, 7-18 cells thick in $P$. urinaria and 6-12 cells thick in $P$. odontadenius and $P$. niruroides and5-7 cells thick in $P$. muellerianus. The innermost layer of the cortex which is the endodermis is one layer thick in the five species. The vascular bundles contained both xylem and phloem with xylem being more prominent. The xylem size varied from $10-53 \mu \mathrm{m}$ in $P$. amarus, $11-43 \mu \mathrm{m}$ in $P$. urinaria, $15-62 \mu \mathrm{m}$ in $P$. odontadenius, $12-47 \mu \mathrm{m}$ in $P$. niruroides and $12-40 \mu \mathrm{m}$ in $P$. muellerianus while the phloem varied from 4-6 cells in $P$. amarus, 4-8 cells in $P$. urinaria, 5-8 cells in $P$. odontadenius, 3-5 cell in $P$. niruroides and $P$. muellerianus respectively. 

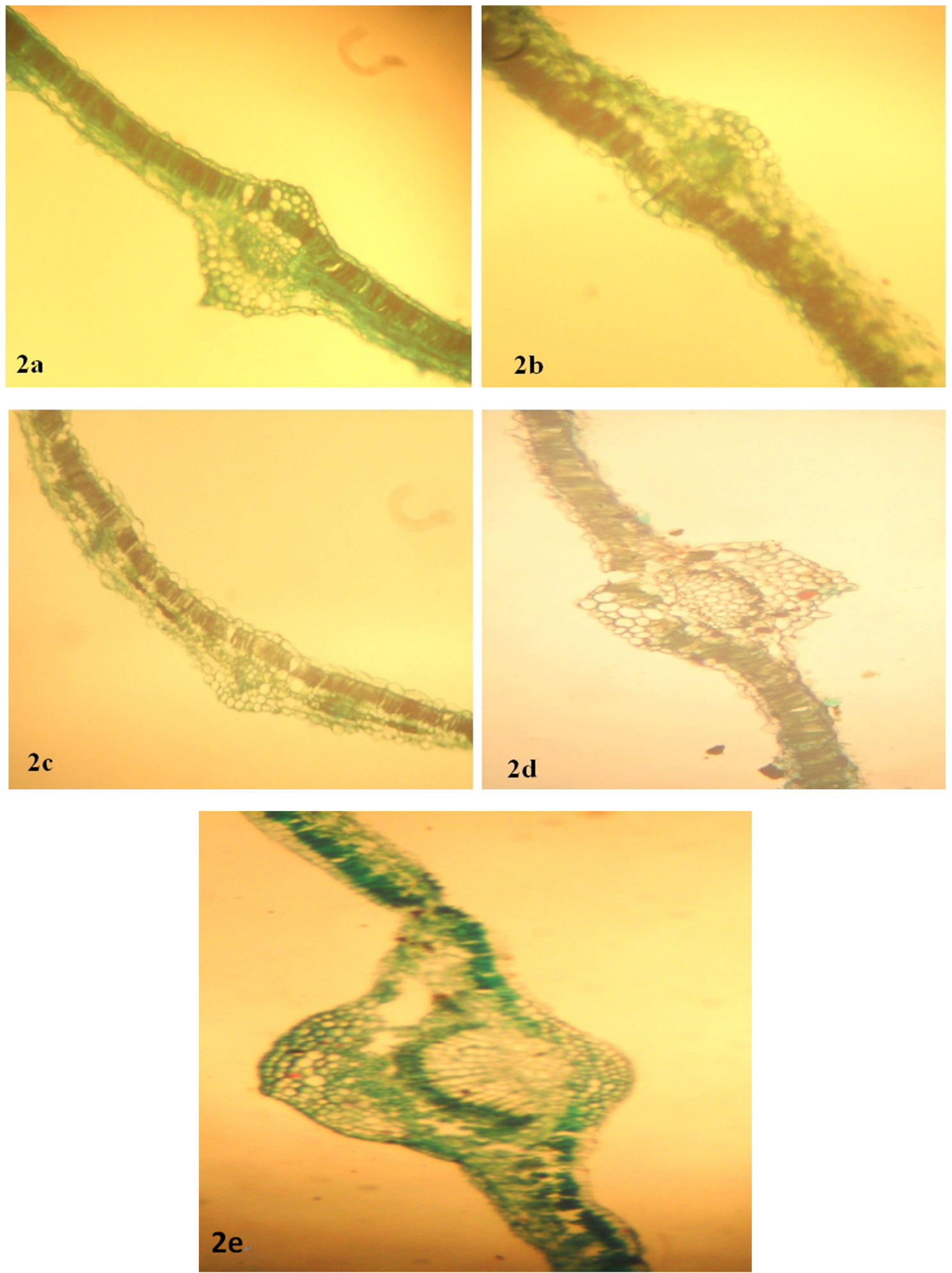

Figure 2. Transverse section of the leaf of the genus Phyllanthus studied.

(a) P. amarus - showing the tissue arrangement around the mid rib (x 200)

(b) P. urinaria - showing the tissue arrangement around the mid rib (x 200)

(c) P. odontadenius - showing the tissue arrangement around the mid rib (x 200)

(d) P. niruroides - showing the tissue arrangement around the mid rib (x 200)

(e) P. muellerianus - showing the tissue arrangement around the mid rib (x 200) 

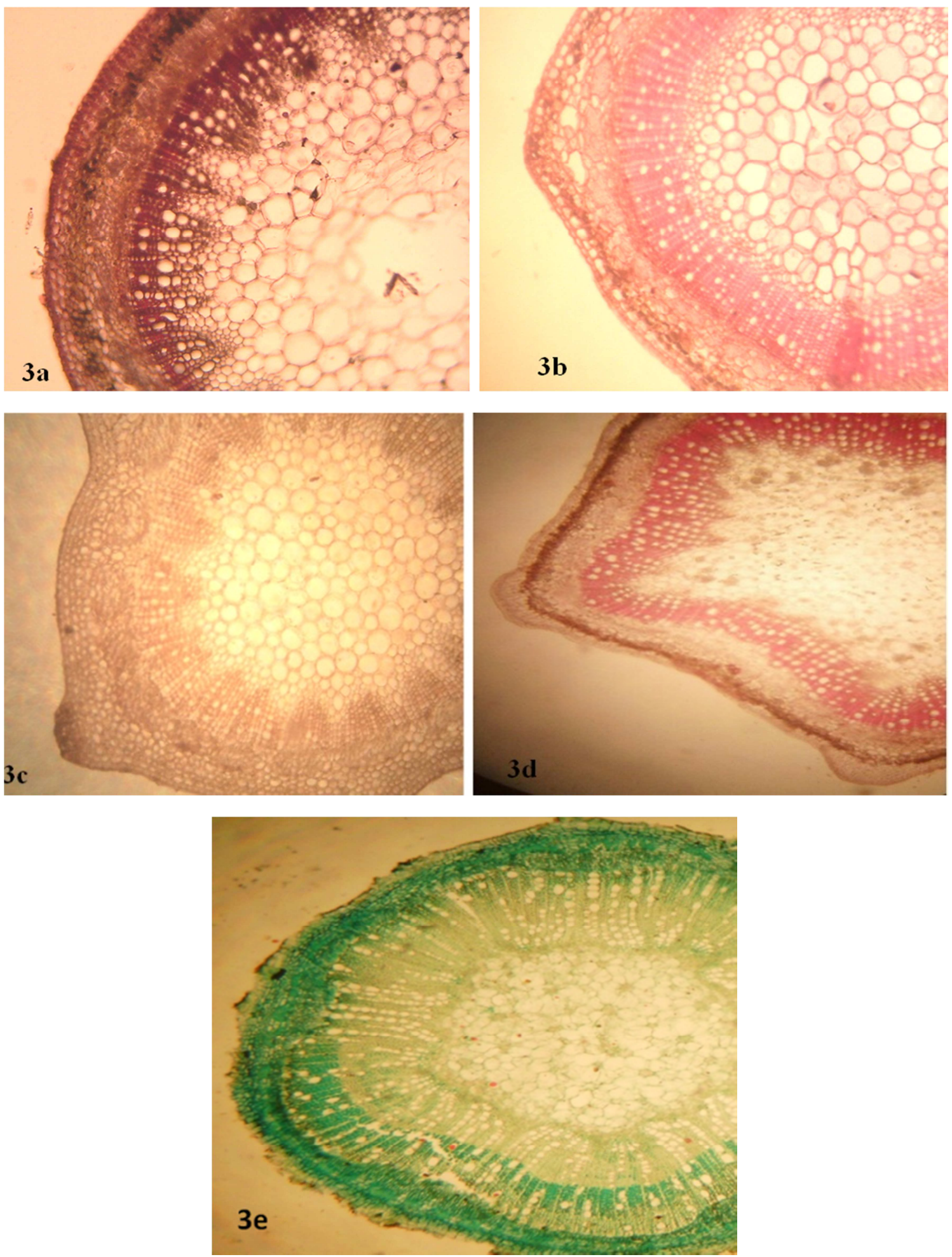

Figure 3. Transverse section of the stem of the genus Phyllanthus studied.

(a) P. amarus - showing the pith, arrangement of the cells in the cortex and rounded edges of the stem epidermis (x 100)

(b) P. urinaria - showing the pith, arrangement of the cortex cells and the angular edges of the stem epidermis (x 100)

(c) P. odontadenius - showing the pith, arrangement of the cortex cells and the angular edges of the stem epidermis ( $\mathrm{x} 100)$

(d) P. niruroides - showing the pith, arrangement of the cortex cells and the angular edges of the stem epidermis ( $\mathrm{x} 100$ )

(e) P. muellerianus - showing the pith, arrangement of the cortex cells and rounded edges of the stem epidermis ( $\mathrm{x} 100$ ) 

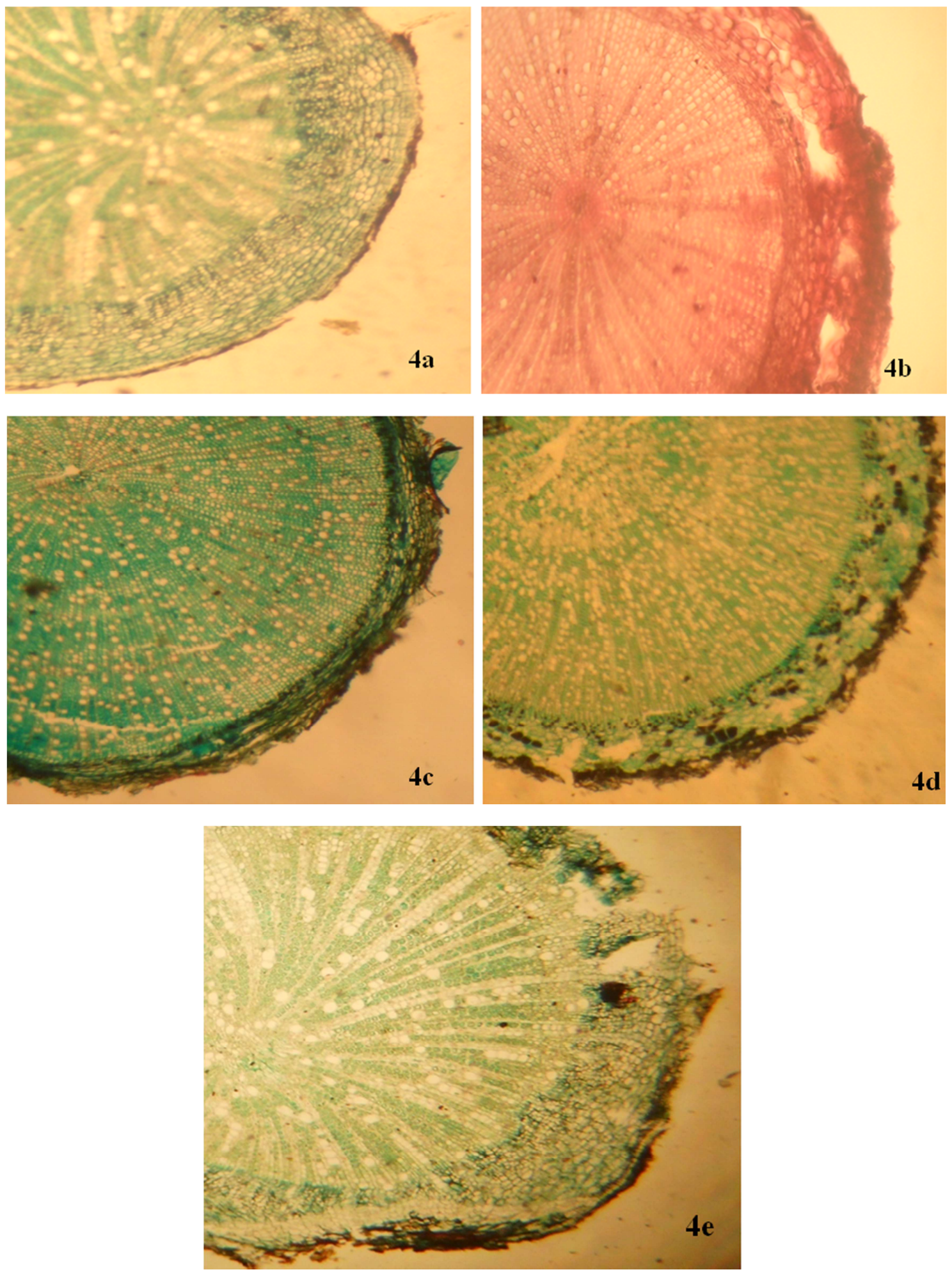

Figure 4. Transverse section of the root of the genus Phyllanthus studied.

(a) P. amarus - showing the cork cells and cortex (x 100)

(b) P. urinaria - showing the cork cells and cortex (x 100)

(c) P. odontadenius - showing the cork cells and cortex (x 100)

(d) P. niruroides - showing the cork cells and cortex (x 100)

(e) P. muellerianus - showing the cork cells and cortex (x 100) 
Table 3. Summary of the Anatomical Characters of the Phyllanthus species studied

\begin{tabular}{|c|c|c|c|c|c|}
\hline CHARACTERS & P. amarus & P. urinaria & P. odontadenius & P. niruroides & P. muellerianus \\
\hline \multicolumn{6}{|l|}{ LEAF } \\
\hline $\begin{array}{l}\text { Number of palisade } \\
\text { parenchyma in the } \\
\text { mesophyll }\end{array}$ & 2 layer thick & 2 layer thick & 1 layers thick & 2 layers thick & 1 layer thick \\
\hline $\begin{array}{l}\text { Nature of intercellular } \\
\text { spaces }\end{array}$ & Small & Large & Large & Small & Large \\
\hline $\begin{array}{l}\text { Nature of xylem cells } \\
\text { within the mid rib }\end{array}$ & $\begin{array}{l}\text { Elongated cells } 2 \text { layers } \\
\text { thick }\end{array}$ & $\begin{array}{l}\text { Clustered cells } 2 \\
\text { layers thick }\end{array}$ & $\begin{array}{l}\text { Clustered cells } 3 \\
\text { layers thick }\end{array}$ & $\begin{array}{l}\text { Elongated cells } 6 \\
\text { layers thick }\end{array}$ & $\begin{array}{l}\text { Elongated cells } 7 \\
\text { layers thick }\end{array}$ \\
\hline \multirow{2}{*}{$\begin{array}{l}\text { Distribution of the } \\
\text { collenchyma cells within } \\
\text { the midrib }\end{array}$} & 1-2 layers on adaxial & None on adaxial & None on adaxial & 1-3 layers on adaxial & 1-6 layers on adaxial \\
\hline & 2-4 layers on abaxial & 1-2 layers on abaxial & 1-2 layers on abaxial & 2-5 layers on abaxial & 2-9 layers on abaxial \\
\hline \multicolumn{6}{|l|}{ STEM } \\
\hline Epidermal circumference & Rounded & Angular & Angular & Angular & Rounded \\
\hline Ridges and Furrows & Absent & Present & Present & Present & Absent \\
\hline \multirow{3}{*}{$\begin{array}{l}\text { Hypodermis } \\
\text { (Collenchyma) }\end{array}$} & Rectangular & Rectangular & Rectangular & Oval & Rectangular \\
\hline & 2-3 layers thick & $\begin{array}{l}2-5 \text { layers thick on } \\
\text { ridges }\end{array}$ & $\begin{array}{l}3-5 \text { layers thick on } \\
\text { ridges }\end{array}$ & $\begin{array}{l}3-4 \text { layers thick on } \\
\text { ridges }\end{array}$ & 3-5 layers thick \\
\hline & -- & $\begin{array}{l}\text { 1-2 layers thick on } \\
\text { furrows }\end{array}$ & $\begin{array}{l}\text { 2-3 layers thick on } \\
\text { furrows }\end{array}$ & $\begin{array}{l}\text { 1-2 layers thick on } \\
\text { furrows }\end{array}$ & -- \\
\hline \multirow{2}{*}{ Cortex (Parenchyma) } & Oval & Oval \& polygonal & Oval \& polygonal & Oval & Oval \& rectangular \\
\hline & 4-6 layers thick & 2-5 layers thick & 2-3 layers thick & 2-5 layers thick & 5-7 layers \\
\hline Pericycle (Sclerenchyma) & 2-3 layers thick & 2-4 layers thick & 1-2 layers thick & 3-4 layers thick & 2-3 layers thick \\
\hline Xylem cells & 3-6 elongated cells & 2-5 elongated cells & 2-5 elongated cells & 2-8 elongated cells & 5-13 elongated cells \\
\hline Phloem & 4-9 layers thick & 3-5 layers thick & 4-9 layers thick & 2-7 layers thick & 3-5 layers thick \\
\hline \multicolumn{6}{|l|}{ ROOT } \\
\hline Cork cells & $5-9$ cells thick & 8-11 cells thick & $6-9$ cells thick & 2-4 cells thick & 3-5 cells thick \\
\hline Cortex & $10-15$ cells thick & $7-18$ cells thick & $6-12$ cells thick & $6-12$ cells thick & 5-7 cells thick \\
\hline Xylem & $10-53 \mu \mathrm{m}$ & $11-43 \mu \mathrm{m}$ & $15-62 \mu \mathrm{m}$ & $12-47 \mu \mathrm{m}$ & $12-40 \mu \mathrm{m}$ \\
\hline Phloem & 4-6 cells thick & $4-8$ cells thick & $5-8$ cells thick & $3-5$ cells thick & 3-5 cells thick \\
\hline
\end{tabular}

\subsection{Dichotomous Bracketed Key to the Leaf Anatomy Identification of the Species of Phyllanthus Studied}

1. Nature of intercellular spaces, small 2.

$1^{\mathrm{I}}$. Nature of intercellular spaces, large 3.

2. Nature of xylem cells within the midrib, 2 layers thick P. amarus.

$2^{\mathrm{I}}$. Nature of xylem cells within the midrib, 6 layers thick P. niruroides.

3. Number of palisade parenchyma in the mesophyll, 2 layers thick .... P. urinaria.

$3^{\mathrm{I}}$.Number of palisade parenchyma in the mesophyll, 1 layer thick 4.

4. Collenchyma cells distributed present within the adaxial portion of the midrib; xylem cells, elongated. ............ P. muellerianus.

4. Collenchyma cells not distributed but absent within the adaxial portion of the Midrib; xylem cells, clustered.

............ P. odontadenius.

\subsection{Dichotomous Bracketed Key to the Stem Anatomy Identification of the species of Phyllanthus studied.}

1. Epidermal circumference, angular; ridges and furrows, present 2 .

${ }^{1}$. Epidermal circumference, rounded; ridges and furrows, absent 3.

2. Hypodermal collenchyma, oval ...... P. niruroides.

$2^{\mathrm{I}}$. Hypodermal collenchyma, not oval but rectangular 4.

3. Cortex parenchyma, rectangular and oval P. muellerianus.

$3^{\mathrm{I}}$. Cortex parenchyma, never rectangular but oval ..... P. amarus.

4. Phloem tissues, less abundant, 3-5 layers thick ...... P. urinaria. $4^{\mathrm{I}}$. Phloem tissues, much abundant, 4-9 layers thick ....... 


\section{Discussion}

Morphologically, the shrub habit and the presence spiny stipules in P. muellerianus as against the herbaceous nature and laterally free stipules of the other species are distinguishing spot characters which clearly delimits $P$. muellerianus. Other peculiar characters such as sub-acute leaf apex and ovate-elliptic leaf shape are also taxonomic attributes of the taxon. Among other species studied, $P$. amarus seems to be the only taxon that exhibited an ellipticoblong leaf, greenish stipules and all-rounded stem form. This peculiar character presented a spot delimiting character since other herbaceous species lack the attributes. Although some overlapping characters within $P$. urinaria, $P$. niruroides and $P$. odontadenius in possessing reddish stipules and oblong leaf shapes, the number of tepals could be seen as a strong delimiting character in separating $P$. niruroides from $P$. urinaria and $P$. odontadenius. $P$. niruroides possessed 5 tepals while $P$. urinaria and $P$. odontadenius possessed 6 tepals respectively. Moreover, the fruits of $P$. niruroides are often spotted while other taxa are not. Also, the leaf apices and fruit colour in P. urinaria and $P$. odontadenius displayed a clear character spot in separating the two taxa. $P$. urinaria possessed a mucronate leaf apex and reddish fruit while $P$. odontadenius lacked the attribute but rather possessed an obtuse leaf apex and an entirely greenish fruits.

The conspicuous nature and thickness of the epidermis of the leaves among the five species of Phyllanthus conformed to the opinion of Metcalfe and Chalk (1950) in dicotyledons. The epidermis is one layer thick and conspicuously visible in the five species investigated. On the contrary, there is a variation in the nature of intercellular spaces, which showed a line of evidence among the different groups of the taxa. $P$. amarus and $P$. niruroides possessed small intercellular spaces while $P$. urinaria, $P$. odontadenius and $P$. muellerianus possessed large intercellular spaces. But P. amarus can be separated from $P$. niruroides with the nature of xylem cells within the midrib in which $P$. amarus (Fig. 2a) is 2 layers thick while $P$. niruroides (Fig. 2d) is 6 layers thick. Among the taxa (P. urinaria, P. odontadenius and P. muellerianus) possessing large intercellular spaces in the mesophyll, the number of palisade parenchyma differed among them. This can be of taxonomic value in drawing the line among the taxa, 2 layers thick in P. urinaria (Fig. 2b) but 1 layer thick in $P$. odontadenius and $P$. muellerianus respectively. The distribution of the collenchyma cells within the midrib can also be of taxonomic evidence in separating $P$. odontadenius and $P$. muellerianus in which the tissues were found absent on the adaxial portion but present only on the abaxial portion in P. odontadenius (Fig. 2c) while P. muellerianus (Fig. 2e) possessed them on both the abaxial and adaxial portions. Also, the nature of the xylem cells differed between both taxa in which $P$. odontadenius possessed 3 layers of clustered xylem cells while $P$. muellerianus possessed 7 layers of elongated xylem cells. Metcalfe and Chalk (1950) used the anatomical arrangement of mesophyll layers in taxonomic conclusion of the species of Phyllanthus.
The variable characteristics possessed in the anatomy of the stem of the Phyllanthus species studied could be valuable in characterization. $P$. urinaria, $P$. odontadenius and $P$. niruroides possessed ridges and furrows which are passed over by a single outer layer of epidermis. The presence of the ridges and furrows were as result the angular nature of the stem circumference. This feature is absent in $P$. amarus and $P$. muellerianus due to the rounded stem circumference. With this, P. amarus and P. muellerianus can be separated from other taxa. But $P$. amarus can be further separated from $P$. muellerianus using the cortex parenchyma in which $P$. amarus (Fig. 3a) is oval while P. muellerianus (Fig. 3e) had a combination of oval and rectangular types within the cortex. The cortical parenchyma or the general cortex ranged from 46 layers thick in $P$. amarus, 2-5 layers thick in $P$. urinaria and $P$. niruroides, 2-3 layers in $P$. odontadenius and 5-7 layers thick in $P$. muellerianus respectively. The hypodermal layer of collenchymas, which differed among the species investigated, could be used in delineating the species. In this study, $P$. niruroides (Fig. 3d) can separated from other taxa in possessing oval type of collenchymas while other species displayed rectangular types. Furthermore, the possession of phloem tissues, which varied from 4-9 layers thick in $P$. odontadenius (Fig. 3c) to 3-5 layers thick in P. urinaria (Fig. $3 \mathrm{~b})$ can also be used as a good taxonomic tool to separate both taxa. It should be important to note that only young and matured stems were used for this study. Regions undergoing secondary growth were discarded from the research.

The anatomy of the roots possessed variable characters in the Phyllanthus species studied that could be used in their classification and characterization although they are mostly quantitative and overlapping. The possession of cork cells, which varied from 5-9 cells thick in $P$. amarus, 8-11 cells thick in $P$. urinaria, 6-9 cells thick in $P$. odontadenius, $2-4$ cells thick in $P$. niruroides and 3-5 cells thick in P. muellerianus separates the various taxa from themselves. The cortex ranged from 1015 cells thick in $P$. amarus, 7-18 cells thick in $P$. urinaria, 612 cells thick in $P$. odontadenius and $P$. niruroides and 5-7cells thick in P. muellerianus. Another feature in the root which is of systematic value is the vascular bundles. The xylem size varied from $10-53 \mu \mathrm{m}$ in P. amarus, $11-43$ in P. urinaria, $15-62 \mu \mathrm{m}$ in $P$. odontadenius, $12-47 \mu \mathrm{m}$ in P. niruroides and $12-40 \mu \mathrm{m}$ in $P$. muellerianus. The phloem also varied from 4-6 cells thick in $P$. amarus, 4-8cells thick in $P$. urinaria, 5-8 cells thick in $P$. odontadenius, 3-5 cells thick in $P$. niruroides and $P$. muellerianus respectively. The observation supports earlier studies of Edeoga and Okoli (1997); Edeoga et al. (2007) which revealed how the stellar arrangement has exhibited constancy in different plants and plant organs.

\section{Conclusion}

The morphological and anatomical studies of the leaves, stems and roots of the Phyllanthus species has provided additional evidence which may be combined with other existing lines of taxonomic evidence in arriving at a better identification and classification of Phyllanthus species. 


\section{References}

[1] Airy-Shaw, H. K. (1985). A Dictionary of Flowering Plants and Ferns. 1245 p.

[2] Akobundu, I. O. and Agyaka, C. W. (1987). A Hand book of Agriculture West African Weeds. International Institute of Tropical Agriculture, Ibadan.521 p.

[3] Burkill, H. M. (1994). The Useful Plants of West Tropical Africa. Vol.2.Families E-I . Royal Botanic Garden, Kew. p. 605.

[4] Cabieses, F. (1993). Apuntes de medicinatrational. La Racionalizcion de lo Irracional. "Notes on Traditional Medicine". ConsejoNacional de Ciencia Y Technologia CONCYTEC Lima-Peru. 414p.

[5] Cutler, D. F. (1978) Applied Plant Anatomy. Longman, London. $102 \mathrm{p}$.

[6] David, J. Mabberly (2008). Mabberley's Plant Book. $3^{\text {rd }}$ edition. Cambridge University Press. 456p.

[7] Edeoga, H. O. and Okoli, B. E. (1997). Anatomy and Systematics in the Costus afer-C lucansianus. complex (Costaceae). ActaPhytotaxGeoba.,; 48:151-158

[8] Edeoga, H. O., Omosun, G., Osuagwu, G. G. and Awomukwu, D. A. (2007). Anatomical Features of vegetative organs of Phyllanthus species. Environ \& Ecology., 25 (3): 548-553

[9] Gill, L. S. (1992). Ethnomedicinal Uses of Plants in Nigeria, University of Benin Press. Nigeria. p. 276.

[10] Hutchinson, J. and Dalziel, J. M. (1963). Flora of West Tropical Africa. vol. 2 Crown Agent, London. pp. 384-388.

[11] Kathriarachchi, H., Hoffmann, P., Samuel, R., Wurdack, K. J. and Chase, M. W. (2005). Molecular phylogenetics of Phyllanthaceae inferred from five genes (plastid atpB, matK, 30ndhF, rbcL, and nuclear PHYC). Molecular Phylogenetics and Evolution, 36: 112-134.

[12] Lawson, J. R. S (1967). A Key to the Dioscorea species in Nigeria. J. West Afr. Sci. Asso., 12:1-9
[13] Lewis, W. H. and Elvin-Lewis, P. F. (1977). Medical Botany Plants Affecting Man`s Health. A widely Inter science Publication. John Wiley \& Sons, New York-London-SydneyToronto. $515 \mathrm{p}$.

[14] Metcalfe, C. R. and Chalk, L. (1950).Anatomy of the Dicotylendons. Clarendon Press, Oxford, London

[15] Natural Remedies Research Centre (2006). Phyllanthus amarus Master Document. Quality Control Dept. Hosur Road, Bangalore. $61 \mathrm{p}$.

[16] Oliver, B. (1959). Nigeria`s Useful Plants II (1) Nig. Fields 24:13-34

[17] Onwuememe, I. C. (1978).The Tropical Tuber Crops: yam, cassava, sweet potato and cocoyam. John Wiley and Sons. Chicelster.234 p.

[18] Samuel, R., Kathriarachchi, H., Hoffmann, P., Barfuss, M. H. J., Wurdack, K. J., Davis, C. C. and Chase, M. W. (2005). Molecular phylogenetics of Phyllanthaceae: evidence from plastid matK and nuclear PHYC sequences. American Journal of Botany, 92: 132-141.

[19] Sofowara, A (1993) Medicinal plants and Tradiocinal medicine in Africa, Spectrum Books LTD. Ibadan, Nigeria. 289 p.

[20] Stace, C. A. (1980) Plant Anatomy and Biosystematics. Edward Arnold Publishers, London. 279 p.

[21] Uander, D. W. and Blumberg, B. S. (1991). In vitro activity of Phyllanthus species (Euphorbiaceae) against the DNA polymerase of hepatitis virus; effect of growing environment and inter and intra-specific differences. Economy Botany, 45: $225-242$.

[22] Wessels-Boer, J. G., Hekking, W. H. A and Schulz, J. P. (1976) Fa Joe Kantak' mi no moi. Inleiding in de flora en vegetative van Suriname; Deel I en II "Why do say that I am not beautiful". Introduction to the flora and vegetation of Suriname; Part I and II" Natuurgidsserie B. No. 4 Stinasu Paramaribo

[23] Wurdack, K. J., Hoffmann, P., Samuel, R., De Bruijn, A. Y., Van Der Bank, M. and Chase, M. W. (2004). Molecular phylogenetic analysis of Phyllanthaceae (Phyllanthoideae pro parte, Euphorbiaceae sensulato) using plastid rbcL DNA sequences. American Journal of Botany, 91:1882-1900. 